\title{
Association of Thymic Stromal Lymphopoietin Receptor (TSLPR) Polymorphisms with the Susceptibility of Rheumatoid Arthritis in a Korean Population
}

\author{
Ji-in Yu, Ji-Su Mo and Soo-Cheon Chae* \\ Department of Pathology, School of Medicine, Wonkwang University, Chonbuk 570-749, Korea
}

Received April 5, 2013 /Revised July 9, 2013 /Accepted July 12, 2013

\begin{abstract}
Human thymic stromal lymphopoietin receptor (TSLPR) might play an important role in the development of inflammatory and allergic responses. We previously identified eleven single nucleotide polymorphisms (SNPs) and two variation sites in the TSLPR gene and showed that all the SNPs of the $T S L P R$ gene are associated with susceptibility to atopic asthma. The present study aimed to investigate whether the TSLPR gene SNPs are associated with susceptibility to rheumatoid arthritis (RA). We compared the genotype and the allele frequencies of the TSLPR SNPs in 457 RA patients and 570 healthy controls. The genotype and the allele frequencies of the TSLPR gene SNPs in the RA patients were not significantly different from the respective frequencies of the healthy controls. Additional analysis showed that the genotype and the allele frequencies of the TSLPR gene SNPs did not appear to be associated with RA in female RA patients. The TSLPR gene SNPs in the RA patients did not affect the production of rheumatoid factor (RF) and antisynthetic cyclic citrullinated peptide (CCP). Our results suggest that the TSLPR gene SNPs are not associated with susceptibility to RA in the Korean population.
\end{abstract}

Key words : Autoimmune disease, CRLF2, polymorphism, rheumatoid arthritis (RA), thymic stromal lymphopoietin receptor (TSLPR)

\section{Introduction}

Rheumatoid arthritis (RA) is one of the most common autoimmune diseases. RA comes about through the complex interaction between multiple genetic factors as well as environmental factors [8]. RA is characterized by inflammation of synovial tissues and the formation of rheumatoid pannus, which is capable of eroding adjacent cartilage and bone and causing subsequent joint destruction. A characteristic feature of RA is the presence of rheumatoid factors (RFs) and RF-containing immune complexes in both the circulation and synovial fluid [7]. RFs are auto-antibodies that recognize the Fc region of immunoglobulin G (IgG) antibodies and their isotypes. RF has been widely used as a screening test for patients with arthritis. RF is prognostically useful to correlates with functional [18] and outcomes in both RA and early inflammatory polyarthritis [9]. A highly specific auto-

\footnotetext{
*Corresponding author

Tel : +82-63-850-6793, Fax : +82-63-852-2110

E-mail : chaesc@wonkwang.ac.kr

This is an Open-Access article distributed under the terms of the Creative Commons Attribution Non-Commercial License (http://creativecommons.org/licenses/by-nc/3.0) which permits unrestricted non-commercial use, distribution, and reproduction in any medium, provided the original work is properly cited.
}

antibody system has been recently described for RA, in which the synthetic cyclic citrullinated peptide (CCP) with deiminated arginines is used as the antigen for the anti-CCP antibodies [14]. Anti-CCP antibodies are locally present at the site of inflammation in RA [13], and citrullinated proteins are found in the RA synovium [3].

Thymic stromal lymphopoietin (TSLP) has been proposed to signal through a heterodimeric receptor complex, which is composed of the TSLP receptor (TSLPR) and the IL-7R alpha chain $[11,12]$. Human TSLP is involved in dendritic cell (DC) maturation $[15,19]$ and it is produced by epithelial cells, stromal cells and mast cells. We previously showed that the single nucleotide polymorphisms (SNPs) of TSLP were associated with the susceptibility to allergic rhinitis [22]. The human TSLPR gene is located on chromosome Xp22.3 and Yp11.3, and it consists of seven (NM_001012288.1, isoform 2) or eight exons (NM_022148.2, isoform 1). TSLPR contains two fibronectin type III-like domains, four conserved cysteine residues and a WSXWS (Trp-Ser-X-Trp-Ser) box-like motif that is typical for type I cytokine receptors. The C-terminal intracellular region contains a membrane-proximal Box 1 motif, which also functions as a putative binding site for signal transduction molecules $[17,23]$. The TSLPR knockout mice have normal num- 
bers of lymphocytes, but the TSLPR $/ \gamma_{\mathrm{c}}$ double knockout mice display a greater lymphoid defect than the $\gamma_{\mathrm{c}}$ KO mice [1]. Leonard and coworkers have also reported that these mice exhibit strong Th1 responses with high levels of interleukin (IL)-12, interferon- $\gamma$ and immunoglobulin IgG2a, but low levels of IL-4, IL-5, IL-10, IL-13 and IgE [2]. TSLPR knockout mice fail to develop an inflammatory lung response to inhaled antigen unless they are supplemented with wild-type $\mathrm{CD} 4^{+} \mathrm{T}$ cells [2]. These results indicated that TSLPR plays an important role in the development of inflammatory and/or allergic responses. Shi and coworkers have recently suggested that the local application of anti-TSLPR prevented Th2- mediated airway inflammation by regulating the function of DCs, and this might be exploited to develop novel treatments for asthma [16]. We previously identified eleven single nucleotide polymorphisms (SNPs) and two variation sites in human TSLPR gene, and suggested that the SNPs of the TSLPR gene were associated with the susceptibility to atopic asthma in the Korean population [21].

To determine whether the SNPs of the TSLPR gene are associated with the susceptibility of RA, we analyzed the allelic and genotypic frequencies between the RA patients and the healthy controls. We further investigated the relationships between the genotypes of each polymorphism and the anti-CCP antibody or RF levels in the RA patients. Finally, we calculated the haplotype frequencies that were constructed by these SNPs in both groups.

\section{Materials and Methods}

\section{Patients and DNA samples}

The DNA samples used in this study were provided by the Biobank of Wonkwang University Hospital, which is a member of the National Biobank of Korea and this Biobank is supported by the Ministry of Health, Welfare and Family Affairs. On the basis of approval and informed consent from the institutional review board, we obtained the genomic DNAs from 457 RA patients and 570 healthy controls. The clinical parameters of the study subjects are summarized in Table 1. Genomic DNA was extracted from the leukocytes in the peripheral blood by a standard phenol-chloroform method or by using a Genomic DNA Extraction kit (iNtRON Biotechnology, Sungnam, Korea) according to the manufacturer's directions. RA was diagnosed according to the criteria of the American Rheumatism Association. Anti-CCP
Table 1. Clinical characteristics of the study subject

\begin{tabular}{lcc}
\hline & $\mathrm{RA}^{\mathrm{a}}$ & Control $^{\mathrm{a}}$ \\
\hline Number of subjects & 457 & 570 \\
Age (yr) & $53.1 \pm 12.2$ & $40.6 \pm 7.0$ \\
Gender (male/female) & $87 / 370$ & $356 / 214$ \\
Total IgE (IU/ml) & $70.8 \pm 68.3$ & - \\
Anti-CCP antibody (U/ml) & $49.5 \pm 46.1$ & - \\
\hline
\end{tabular}

${ }^{\mathrm{a}}$ Data are means \pm standard deviation

antibody level in the RA patients was determined by enzyme-linked immunosorbent assay (ELISA) using DIASTAT anti-CCP antibody kit (MBL Co, Nagoya, Japan) and read by automated EIA analyzer, CODA (Bio-RAD Co, Tokyo, Japan). Anti-CCP antibody was considered positive when the absorbance was higher than the cut-off value $(5 \mathrm{U} / \mathrm{ml})$. The concentration of anti-CCP antibody was estimated by interpolation from a dose-response curve based on standards. RF level in the RA patients was measured by the latex fixation test using Hitachi $7170 \mathrm{~S}$ (Hitachi Co, Tokyo, Japan). The cutoff for positivity was $18 \mathrm{IU} / \mathrm{ml}$ for RF. The non-rheumatoid arthritis healthy controls were recruited from the general population who underwent comprehensive medical testing at Wonkwang University Hospital. All the subjects in this study were Korean.

\section{Genotype analysis}

Genotype analysis of the TSLPR SNPs were performed by high resolution melting (HRM) analysis (g. $43 \mathrm{~T}>\mathrm{C}$, g.19646A $>\mathrm{G}$ and g.21995T>C), single-base extension (SBE) method (g.21884G>A), and Taq-man assay probes (g.33G>C and g.21869T $>C$ ) according to the previously described method [21]. The PCR cycling for HRM analysis was carried out using the Rotor-Gene thermal cycler RG6000 (Corbett Research, Sydney, Australia). The PCR cycling conditions were as follows; one cycle of $95^{\circ} \mathrm{C}$ for $15 \mathrm{~min}, 45$ cycles of $95^{\circ} \mathrm{C}$ for $5 \mathrm{sec}$ (g. $-43 \mathrm{~T}>\mathrm{C}$ ) or $15 \mathrm{sec}$ (g.19646A>G and g.21995T $>\mathrm{C}$ ), $58^{\circ} \mathrm{C}$ (g.21995T $>\mathrm{C}$ ) or $60^{\circ} \mathrm{C}$ (g. $43 \mathrm{~T}>\mathrm{C}$ and g. $19646 \mathrm{~A}>\mathrm{G}$ ) for $10 \mathrm{sec}$ and $72^{\circ} \mathrm{C}$ for $15 \mathrm{sec}(\mathrm{g} .43 \mathrm{~T}>\mathrm{C})$ or $30 \mathrm{sec}$ (g.19646A $>\mathrm{G}$ and g.21995T $>$ C). PCR for SBE analysis was performed with $50 \mathrm{ng}$ each of genomic DNA and Taq DNA polymerase (Solgent, Daejeon, Korea) and $0.5 \mu \mathrm{M}$ of each primer under the following conditions: 30 cycles of denaturation at $98^{\circ} \mathrm{C}$ for $10 \mathrm{sec}$, annealing at $55^{\circ} \mathrm{C}$ for $10 \mathrm{sec}$ and extension at $72^{\circ} \mathrm{C}$ for $30 \mathrm{sec}$. The final extension was completed at $72^{\circ} \mathrm{C}$ for $10 \mathrm{~min}$ in a thermocycler (PE Applied Biosystem, Foster city, USA). The Taq-man assay probes for g.33G $>C$ and g.21869T $>C$ were designed by Integrated DNA 
Technologies (IDT, Coralville, USA). FAM-fluorescence dye was attached to the TSLPR-1G, TSLPR-2T probe and the HEX-fluorescence dye was attached to the TSLPR-1C, TSLPR-2C probe [21]. The PCR conditions were as follows: one cycle at $95^{\circ} \mathrm{C}$ for $15 \mathrm{~min}, 50$ cycles at $95^{\circ} \mathrm{C}$ for $15 \mathrm{sec}$ and $64^{\circ} \mathrm{C}$ for $40 \mathrm{sec}$. The PCR was performed in the Rotor-Gene thermal cycler RG6000 (Corbett Research, Sydney, Australia). The samples were read and analyzed using the software Rotor-Gene 1.7.40 (Corbett Research, Sydney, Australia).

\section{Statistic analysis}

The RA patients and healthy controls were compared using case-control association analysis. $x^{2}$ tests were employed to estimate the Hardy-Weinberg equilibrium (HWE). Pair-wise comparison of the biallelic loci was employed for the analyses of linkage disequilibrium (LD). The haplotype frequencies of TSLPR for multiple loci were estimated using the expectation maximization (EM) algorithm with SNPAlyze software (DYNACOM, Yokohama, Japan). Logistic regression analyses (SPSS 11.5) were used to calculate the odds ratios (with the 95\% confidence intervals). The ANOVA method was applied to define the ANA levels of each genotype from the individual RA patients. A $P$-value of less than 0.05 was considered to indicate statistical significance.

\section{Results}

\section{Genotype analysis}

To determine whether the TSLPR SNPs are associated

Table 2. Genotype and allele analyses of the TSLPR gene polymorphisms in RA patients and healthy controls

\begin{tabular}{|c|c|c|c|c|c|}
\hline Position $^{\mathrm{a}}$ & $\begin{array}{c}\text { Genotype } \\
\text { /Allele }\end{array}$ & $\begin{array}{c}\text { Control } \\
\mathrm{n}(\%)\end{array}$ & $\begin{array}{c}\text { RA } \\
\mathrm{n}(\%)\end{array}$ & $\begin{array}{c}\text { Odds ratio } \\
(95 \% \text { CI })\end{array}$ & $P^{\varepsilon}$ \\
\hline \multirow{5}{*}{ g. $-43 \mathrm{~T}>\mathrm{C}$} & $\mathrm{TT}$ & $425(76.6)$ & $375(83.0)$ & 1.00 & \multirow{3}{*}{0.002} \\
\hline & $\mathrm{TC}$ & $102(18.4)$ & 71 (15.7) & $0.79(0.57-1.10)$ & \\
\hline & $\mathrm{CC}$ & $28(5.0)$ & $6(1.3)$ & $0.24(0.10-0.59)$ & \\
\hline & $\mathrm{T}$ & $952(85.8)$ & $821(90.8)$ & 1.00 & \multirow{2}{*}{0.001} \\
\hline & $\mathrm{C}$ & $158(14.2)$ & $83(8.2)$ & $0.61(0.46-0.81)$ & \\
\hline \multirow{5}{*}{ g. $33 \mathrm{G}>\mathrm{C}$} & $\mathrm{CC}$ & $520(91.5)$ & $396(88.8)$ & 1.00 & \multirow{3}{*}{0.124} \\
\hline & CG & $48(8.5)$ & $48(10.8)$ & $1.31(0.86-2.00)$ & \\
\hline & GG & $0(0.0)$ & $2(0.4)$ & - & \\
\hline & $\mathrm{C}$ & $1088(95.8)$ & $840(94.2)$ & 1.00 & \multirow{2}{*}{0.100} \\
\hline & G & $48(4.2)$ & $52(5.8)$ & $1.40(0.94-2.10)$ & \\
\hline \multirow{5}{*}{ g.19646A>G } & GG & $250(44.2)$ & $181(40.9)$ & 1.00 & \multirow{3}{*}{0.295} \\
\hline & GA & $242(42.7)$ & $211(47.6)$ & $1.20(0.92-1.57)$ & \\
\hline & AA & 74 (13.1) & 51 (11.5) & $0.95(0.64-1.43)$ & \\
\hline & G & $742(65.5)$ & $573(64.7)$ & 1.00 & \multirow{2}{*}{0.707} \\
\hline & $\mathrm{A}$ & $390(34.5)$ & $313(35.3)$ & $1.04(0.86-1.25)$ & \\
\hline \multirow{5}{*}{$\begin{array}{l}\text { g.21869T }>C \\
\text { (rs36139698) }\end{array}$} & $\mathrm{CC}$ & 408 (72.1) & $333(73.2)$ & 1.00 & \multirow{3}{*}{0.510} \\
\hline & $\mathrm{CT}$ & $147(26.0)$ & $109(24.0)$ & $0.91(0.68-1.21)$ & \\
\hline & TT & 11 (1.9) & $13(2.9)$ & $1.45(0.64-3.27)$ & \\
\hline & $\mathrm{C}$ & $963(85.1)$ & $775(85.2)$ & 1.00 & \multirow{2}{*}{1.000} \\
\hline & $\mathrm{T}$ & 169 (14.9) & $135(14.8)$ & $0.99(0.78-1.27)$ & \\
\hline \multirow{5}{*}{$\begin{array}{l}\text { g.21884G>A } \\
\text { (rs36177645) }\end{array}$} & AA & $249(44.5)$ & $162(37.9)$ & 1.00 & \multirow{3}{*}{0.120} \\
\hline & AG & $260(46.4)$ & $222(52.0)$ & 1.31 (1.01-1.71) & \\
\hline & GG & 51 (9.1) & $43(10.1)$ & $1.30(0.83-2.04)$ & \\
\hline & $\mathrm{A}$ & $758(67.7)$ & $546(63.9)$ & 1.00 & \multirow{2}{*}{0.084} \\
\hline & G & $362(32.3)$ & $308(36.1)$ & $1.18(0.98-1.43)$ & \\
\hline \multirow{5}{*}{$\begin{array}{l}\text { g.21995T }>C \\
\text { (rs36133495) }\end{array}$} & $\mathrm{TT}$ & $204(36.4)$ & $163(37.5)$ & 1.00 & \multirow{3}{*}{0.864} \\
\hline & $\mathrm{TC}$ & $274(48.8)$ & $205(47.1)$ & $0.94(0.71-1.23)$ & \\
\hline & $\mathrm{CC}$ & $83(14.8)$ & 67 (15.4) & $1.01(0.69-1.48)$ & \\
\hline & $\mathrm{T}$ & $682(60.8)$ & $531(61.0)$ & 1.00 & \multirow{2}{*}{0.926} \\
\hline & $\mathrm{C}$ & $440(39.2)$ & $339(39.0)$ & $0.99(0.83-1.19)$ & \\
\hline
\end{tabular}

\footnotetext{
${ }^{a}$ Calculated from the translation start site
}

${ }^{\mathrm{b}}$ Logistic regression analyses were used for calculating OR $(95 \% \mathrm{CI}$; confidence interval)

${ }^{c}$ Value was determined by Fisher's exact test or $x^{2}$ test from $2 \times 2$ contingency table 
with the susceptibility of RA, the genotypes of the TSLPR SNPs, g.-43T $>C$ (promoter), g.33G $>C$ (exon 1), g.19646A $>\mathrm{G}$ (exon 7), g.21869T>C (rs36139698, exon 8), g.21884G>A (rs36177645, exon 8) and g.21995T>C (rs36133495, exon 8), were analyzed by the SBE, HRM or TaqMan probe method. Among the previously identified polymorphisms, these six SNPs were selected for genotyping analysis based on their locations and LD block. The genotypes and allele frequencies were compared between the RA patients and the healthy controls. All the genotype frequencies were in HWE, except for the g. $43 \mathrm{~T}>\mathrm{C}$ in the healthy controls (data not shown). The genotype and allele frequencies of TSLPR SNPs were not significantly different between the RA patients and healthy controls (Table 2). The $P$ values in TSLPR SNPs
(g.33G>C, g.19646A >G， g.21869T $>C, \quad$ g.21884G $>A$ and g.21995T $>C$ ) were $0.124,0.295,0.510,0.120$ and 0.864 , respectively. We further analyzed the genotype and allele frequencies between the females of the healthy control group and the RA patients because the RA patients were predominantly female compared with the healthy control subjects. The genotype and allele frequencies of the TSLPR SNPs were not significantly different between the female of the RA patients and the healthy controls (Table 3). These results suggest that the SNPs of the TSLPR gene could not be associated with the susceptibility to RA (Table 2, 3).

\section{Quantitative traits analysis}

On the other hand, to define a possible correlation be-

Table 3. Genotype and allele analyses of the polymorphisms of TSLPR gene polymorphisms in the female of RA patients and healthy controls

\begin{tabular}{|c|c|c|c|c|c|}
\hline Position $^{\mathrm{a}}$ & $\begin{array}{c}\text { Genotype } \\
\text { /Allele }\end{array}$ & $\begin{array}{c}\text { Control } \\
\mathrm{n}(\%)\end{array}$ & $\begin{array}{c}\text { RA } \\
\mathrm{n}(\%)\end{array}$ & $\begin{array}{l}\text { Odds ratio } \\
(95 \% \text { CI })\end{array}$ & $P^{\xi}$ \\
\hline \multirow{5}{*}{ g. $-43 \mathrm{~T}>\mathrm{C}$} & $\mathrm{TT}$ & $161(76.7)$ & $306(83.4)$ & 1.00 & \multirow{3}{*}{0.0005} \\
\hline & $\mathrm{TC}$ & $33(15.7)$ & $56(15.3)$ & $0.89(0.56-1.43)$ & \\
\hline & $\mathrm{CC}$ & $16(7.6)$ & $5(1.4)$ & $0.16(0.06-0.46)$ & \\
\hline & $\mathrm{T}$ & $355(84.5)$ & $668(91.0)$ & 1.00 & \multirow{2}{*}{0.0010} \\
\hline & $\mathrm{C}$ & $65(25.5)$ & $66(9.0)$ & $0.54(0.37-0.78)$ & \\
\hline \multirow{5}{*}{ g. $33 \mathrm{G}>\mathrm{C}$} & $\mathrm{CC}$ & $192(90.6)$ & $324(89.3)$ & 1.00 & \multirow{3}{*}{0.6873} \\
\hline & CG & $20(9.4)$ & $38(10.5)$ & $1.13(0.64-1.99)$ & \\
\hline & GG & $0(0.0)$ & $1(0.3)$ & - & \\
\hline & $\mathrm{C}$ & 404 (95.3) & $686(94.5)$ & 1.00 & \multirow{2}{*}{0.5860} \\
\hline & G & $20(4.7)$ & $40(5.5)$ & $1.18(0.68-2.04)$ & \\
\hline \multirow{5}{*}{ g.19646A>G } & GG & $96(45.7)$ & $136(37.9)$ & 1.00 & \multirow{3}{*}{0.1782} \\
\hline & GA & $92(43.8)$ & $183(51.0)$ & $1.40(0.98-2.02)$ & \\
\hline & $\mathrm{AA}$ & $22(10.5)$ & 40 (11.1) & $1.28(0.72-2.30)$ & \\
\hline & G & $284(67.6)$ & $455(43.4)$ & 1.00 & \multirow{2}{*}{0.1569} \\
\hline & A & $136(32.4)$ & $263(36.6)$ & $1.21(0.94-1.56)$ & \\
\hline \multirow{5}{*}{ g.21869T $>C$} & $\mathrm{CC}$ & $152(72.0)$ & $271(73.4)$ & 1.00 & \multirow{3}{*}{0.4916} \\
\hline & $\mathrm{CT}$ & $56(26.5)$ & $88(23.8)$ & $0.88(0.60-1.30)$ & \\
\hline & $\mathrm{TT}$ & $3(1.4)$ & $10(2.7)$ & $1.87(0.51-6.90)$ & \\
\hline & $\mathrm{C}$ & $360(85.3)$ & $630(85.4)$ & 1.00 & \multirow{2}{*}{1.0000} \\
\hline & $\mathrm{T}$ & $62(14.7)$ & 108 (14.6) & $1.00(0.71-1.40)$ & \\
\hline \multirow{5}{*}{ g. $21884 \mathrm{G}>\mathrm{A}$} & AA & 92 (44.2) & 137 (39.4) & 1.00 & \multirow{3}{*}{0.5273} \\
\hline & AG & 99 (47.6) & $181(52.0)$ & $1.23(0.86-1.76)$ & \\
\hline & GG & $17(8.2)$ & $30(8.6)$ & $1.19(0.62-2.27)$ & \\
\hline & $\mathrm{A}$ & $283(68.0)$ & $455(65.4)$ & 1.00 & \multirow{2}{*}{0.3939} \\
\hline & G & $133(32.0)$ & 241 (34.6) & $1.13(0.87-1.46)$ & \\
\hline \multirow{5}{*}{ g. $21995 \mathrm{~T}>\mathrm{C}$} & $\mathrm{TT}$ & $85(40.3)$ & $129(36.3)$ & 1.00 & \multirow{3}{*}{0.4700} \\
\hline & $\mathrm{TC}$ & $99(46.9)$ & 169 (47.6) & $1.13(0.78-1.63)$ & \\
\hline & $\mathrm{CC}$ & $27(12.8)$ & 57 (16.1) & $1.39(0.82-2.37)$ & \\
\hline & $\mathrm{T}$ & $269(63.7)$ & $427(60.1)$ & 1.00 & \multirow{2}{*}{0.2310} \\
\hline & $\mathrm{C}$ & $153(36.3)$ & $283(39.9)$ & $1.17(0.91-1.50)$ & \\
\hline
\end{tabular}

${ }^{a}$ Calculated from the translation start site

${ }^{\mathrm{b}}$ Logistic regression analyses were used for calculating OR $(95 \% \mathrm{CI}$; confidence interval)

c Value was determined by Fisher's exact test or $x^{2}$ test from $2 \times 2$ contingency table 
tween the TSLPR SNPs and the clinical features of RA, we further analyzed the difference of the anti-CCP antibody and RF levels according to each genotype of the RA patients. We found that these SNPs in the RA patients have no significant association with the levels of RF and anti-CCP antibody (Table 4).

\section{Haplotype analysis}

Finally, we estimated the haplotype frequencies of the block 1 (g. $43 \mathrm{~T}>\mathrm{C}$ and g.33G $>\mathrm{C}$ ) and the block 2 (g.21869T>C and g.21884G>A) of the TSLPR gene between the healthy controls and the RA patients (Table 5). Although the CG haplotype frequency was somewhat different in the block
2 of the RA patients, as compared to that of the healthy controls $(p=0.016)$, the distributions of major haplotypes in block 1 and block 2 were not significant difference between the RA patients and the healthy controls. These results suggest that the haplotypes of the TSLPR polymorphisms are not associated with RA susceptibility.

\section{Discussion}

RA is one of the representative autoimmune diseases worldwide. This disease is arisen by the complex interaction between multiple genetic factors and environmental factors [8]. We previously suggested that the exon 4 variations of

Table 4. Analysis of RF and anti-CCP antibody levels among the each genotype of TSLPR gene SNPs in RA patients

\begin{tabular}{|c|c|c|c|c|c|c|c|c|c|}
\hline \multirow{2}{*}{ Position $^{\mathrm{a}}$} & \multirow{2}{*}{ Genotype } & \multicolumn{3}{|c|}{ RF $(1 \mathrm{U} / \mathrm{ml})$} & \multirow{2}{*}{$P^{b}$} & \multicolumn{3}{|c|}{ Anti-CCP antibody } & \multirow{2}{*}{$P^{b}$} \\
\hline & & $\mathrm{n}$ & Mean & SD & & $\mathrm{n}$ & Mean & SD & \\
\hline \multirow{3}{*}{ g. $-43 \mathrm{~T}>\mathrm{C}$} & TT & 370 & 70.992 & 74.1 & \multirow{3}{*}{0.63} & 193 & 48.898 & 44.3 & \multirow{3}{*}{0.55} \\
\hline & $\mathrm{TC}$ & 70 & 72.271 & 75.0 & & 45 & 53.228 & 43.2 & \\
\hline & $\mathrm{CC}$ & 5 & 103.00 & 90.7 & & 2 & - & - & \\
\hline \multirow{3}{*}{ g. $33 \mathrm{G}>\mathrm{C}$} & $\mathrm{CC}$ & 391 & 71.358 & 74.3 & \multirow{3}{*}{0.79} & 211 & 51.202 & 44.1 & \multirow{3}{*}{0.22} \\
\hline & CG & 49 & 68.388 & 76.0 & & 28 & 40.324 & 43.5 & \\
\hline & GG & 2 & - & - & & 2 & - & - & \\
\hline \multirow{3}{*}{ g. $19646 A>G$} & GG & 179 & 68.207 & 75.2 & \multirow{3}{*}{0.58} & 90 & 52.085 & 43.4 & \multirow{3}{*}{0.62} \\
\hline & GA & 209 & 74.359 & 74.3 & & 114 & 46.906 & 45.4 & \\
\hline & $\mathrm{AA}$ & 49 & 63.939 & 74.4 & & 33 & 53.482 & 43.8 & \\
\hline \multirow{3}{*}{ g.21869T $>C$} & $\mathrm{CC}$ & 330 & 71.655 & 74.8 & \multirow{3}{*}{0.83} & 184 & 48.728 & 43.9 & \multirow{3}{*}{0.69} \\
\hline & $\mathrm{CT}$ & 106 & 68.019 & 71.8 & & 54 & 49.725 & 44.9 & \\
\hline & TT & 13 & 61.615 & 79.8 & & 6 & 64.350 & 49.5 & \\
\hline \multirow{3}{*}{ g. $21884 \mathrm{G}>\mathrm{A}$} & $\mathrm{AA}$ & 159 & 72.654 & 75.9 & \multirow{3}{*}{0.56} & 81 & 48.945 & 44.8 & \multirow{3}{*}{0.89} \\
\hline & AG & 220 & 70.300 & 74.1 & & 131 & 50.986 & 44.1 & \\
\hline & GG & 43 & 58.977 & 66.6 & & 19 & 54.084 & 42.0 & \\
\hline \multirow{3}{*}{ g. $21995 \mathrm{~T}>\mathrm{C}$} & TT & 161 & 73.447 & 77.0 & \multirow{3}{*}{0.69} & 91 & 47.113 & 45.2 & \multirow{3}{*}{0.42} \\
\hline & $\mathrm{TC}$ & 203 & 67.340 & 74.0 & & 110 & 53.953 & 43.9 & \\
\hline & $\mathrm{CC}$ & 66 & 73.667 & 71.2 & & 35 & 45.029 & 41.8 & \\
\hline
\end{tabular}

${ }^{a}$ Calculated from the translation start site.

${ }^{\mathrm{b}}$ Values were analyzed by ANOVA

Table 5. The haplotype frequencies by TSLPR gene SNPs in RA patients and healthy controls

\begin{tabular}{|c|c|c|c|c|c|}
\hline \multirow{2}{*}{\multicolumn{3}{|c|}{ Haplotype }} & \multicolumn{2}{|c|}{ Frequency $^{\mathrm{a}}$} & \multirow{2}{*}{$P^{b}$} \\
\hline & & & Control & RA & \\
\hline \multirow{5}{*}{$\begin{array}{c}\text { Block } 1 \\
\text { (g. }-43 \mathrm{~T}>\mathrm{C}, \text { g.33G }>\text { C) }\end{array}$} & $\mathrm{T}$ & C & 0.822 & 0.849 & 0.118 \\
\hline & C & C & 0.135 & 0.093 & 0.003 \\
\hline & $\mathrm{T}$ & G & 0.036 & 0.058 & 0.017 \\
\hline & C & G & 0.007 & $3.0 \mathrm{E}-4$ & 0.021 \\
\hline & C & A & 0.675 & 0.640 & 0.099 \\
\hline \multirow{3}{*}{$\begin{array}{c}\text { Block } 2 \\
(\text { g.21869T }>\text { C, g.21884G }>A)\end{array}$} & C & G & 0.175 & 0.218 & 0.016 \\
\hline & $\mathrm{T}$ & G & 0.147 & 0.141 & 0.717 \\
\hline & $\mathrm{T}$ & A & 0.003 & 0.001 & 0.436 \\
\hline
\end{tabular}

\footnotetext{
${ }^{a}$ Values were constructed by EM algorithm with genotyped SNPs
}

${ }^{\mathrm{b}}$ Values were analyzed by permutation p-value 
the Tim-1 gene [4], the eotaxin-3 polymorphisms [5] and the TBX21 polymorphism [6] are associated with RA susceptibility.

Human TSLP is involved in dendritic cell maturation [15, 19] and it is produced by epithelial cells, stromal cells and mast cells. TSLP is highly expressed in bronchial epithelium and submucosa in allergic asthma [20], and also expressed in synovial fluid specimens derived from RA patients [10]. These results suggest that TSLP might be involved in allergic diseases as well as in inflammatory arthritis such as RA. TSLPR may be plays an important role in the development of inflammatory and/or allergic responses. The human TSLPR has been identified from a human $\mathrm{T}$ lymphocyte and dendritic cell (DC) cDNA library [17, 23]. We previously showed that the expressed levels of TSLPR mRNA by RT-PCR were highest in ovary, pancreas and lung, and they were only barely detected in kidney, heart, thymus and testis, while they were not detected in brain and skeletal muscle [21]. We also identified eleven SNPs and two variation sites in human TSLPR gene, and showed that the g.33G>C and g.19646A>G of the TSLPR gene were associated with the susceptibility to atopic asthma in the Korean population [21].

In this study, we analyzed the genotype of TSLPR SNPs in RA patients and healthy controls. The genotype and allele frequencies of TSLPR SNPs in RA patients were not significantly different from those in the healthy controls group (Table 2). This result suggests that the TSLPR SNPs not associated with the susceptibility to RA. Although the genotype and allele frequencies of $\mathrm{g} .43 \mathrm{~T}>\mathrm{C}$ of TSLPR in RA patients were significantly different from those in the healthy controls group (Table 2, $p=0.002$ and 0.001 , respectively), we exclude it because of the genotype frequencies of g.-43T $>C$ in the healthy controls were not in HWE. The genotype and allele frequencies of the TSLPR SNPs were also not associated with the female RA patients (Table 3). These results suggest that the TSLPR SNPs may be not affected by the gender of RA patients.

The hallmarks of RA are RF and anti-CCP antibody; therefore further evaluation was made to see these SNPs have associations with RF and anti-CCP antibody levels in RA patients. The association levels were measured by ANOVA and compared the relationship. However there are no significant association between the RF and anti-CCP antibody levels and the genotype of TSLPR SNPs in RA patients (Table 4). These results suggest that the TSLPR SNPs are not affected to RF and anti-CCP antibody levels production in RA patients.

The distribution of the major haplotypes (TC in block 1, and CA in block 2) of the TSLPR SNPs in the RA patients was not different from the healthy controls (Table 5). These results suggest that the haplotypes of the TSLPR polymorphisms are not associated with RA susceptibility.

In conclusion, the results of this study suggest that TSLPR not associated with the pathogenesis of RA. However, we have still not comprehensively captured all the diversity in the TSLPR gene, and other associations may still reside at this locus; these associations could not be addressed in the present study. Our study has some limitations that the mean age of healthy controls are lower than that of RA patients. Although the mean age difference between the patient and healthy control groups, it might be not affected in the genetic results of this study.

\section{Acknowledgement}

The genomic DNAs for this study were provided by the Biobank of Wonkwang University Hospital, a member of the National Biobank of Korea, which is supported by the Ministry of Health and Welfare. This paper was supported in part by Soongsan Fellowship in Wonkwang University in 2012.

\section{References}

1. Al-Shami, A., Spolski, R. and Kelly, J. 2004. A role for thymic stromal lymphopoietin in CD4(+) T cell development. J Exp Med 200, 159-168.

2. Al-Shami, A., Spolski, R., Kelly, J., Keane-Myers, A. and Leonard, W. J. 2005. A role for TSLP in the development of inflammation in an asthma model. J Exp Med 202, 829-839.

3. Baeten, D., Peene, I., Union, A., Meheus, L., Sebbag, M., Serre, G., Veys, E. M. and De Keyser, F. 2001. Specific presence of intracellular citrullinated proteins in rheumatoid arthritis synovium: relevance to antifilaggrin autoantibodies. Arthritis Rheum 44, 2255-2262.

4. Chae, S. C., Song, J. H., Shim, S. C., Yoon, K. S. and Chung, H. T. 2004. The exon 4 variations of Tim-1 gene are associated with rheumatoid arthritis in a Korean population. Biochem Biophys Res Commun 315, 971-975.

5. Chae, S. C., Park, Y. R., Shim, S. C., Lee, I. K. and Chung, H. T. 2005. Eotaxin-3 gene polymorphisms are associated with rheumatoid arthritis in a Korean population. Hum Immunol 66, 314-320.

6. Chae, S. C., Shim, S. C. and Chung, H. T. 2009. Association of $T B X 21$ polymorphisms in a Korean population with rheumatoid arthritis. Exp Mol Med 41, 33-41. 
7. Edwards, J. C. and Cambridge, G. 1998. Rheumatoid arthritis: the predictable effect of small immune complexes in which antibody is also antigen. Br J Rheumatol 37, 126-130.

8. Gregersen, P. K. 1999. Genetics of rheumatoid arthritis: confronting complexity. Arthritis Res 1, 37-44.

9. Harrison, B., Thomson, W., Symmons, D., Ollier, B., Wiles, B., Payton, T., Barrett, E. and Silman, A. 1999. The influence of HLA-DRB1 alleles and rheumatoid factor on disease outcome in an inception cohort of patients with early inflammatory arthritis. Arthritis Rheum 42, 2174-2183.

10. Koyama, K., Ozawa, T., Hatsushika, K., Ando, T., Takano, S., Wako, M., Suenaga, F., Ohnuma, Y., Ohba, T., Katoh, R., Sugiyama, H., Hamada, Y., Ogawa, H., Okumura, K. and Nakao, A. 2007. A possible role for TSLP in inflammatory arthritis. Biochem Biophys Res Commun 357, 99-104.

11. Pandey, A., Ozaki, K. and Baumann, H. 2000. Cloning of a novel receptor subunit required for signaling by thymic stromal lymphopoietin. Nat Immunol 1, 59-64.

12. Park, L. S., Martin, U. and Garka, K. 2000. Cloning of the murine thymic stromal lymphopoietin (TSLP) receptor: Formation of a functional heteromeric complex requires interleukin 7 receptor. J Exp Med 192, 659-670.

13. Reparon-Schuijt, C. C., Van Esch, W. J., Van Kooten, C., Schellekens, G. A., de Jong, B. A., van Venrooij, W. J., Breedveld, F. C. and Verweij, C. L. 2001. Secretion of anti-citrulline-containing peptide antibody by B lymphocytes in rheumatoid arthritis. Arthritis Rheum 44, 41-47.

14. Schellekens, G. A., Visser, H., de Jong, B. A., van den Hoogen, F. H., Hazes, J. M., Breedveld, F. C. and van Venrooij, W. J. 2000. The diagnostic properties of rheumatoid arthritis antibodies recognizing a cyclic citrullinated peptide. Arthritis Rheum 43, 155-163.

15. Soumelis, V., Reche, P. A. and Kanzler, H. 2002. Human epithelial cells trigger dendritic cell-mediated allergic inflammation by producing TSLP. Nat Immunol 3, 673-680.

16. Shi, L., Leu, S. W. and Xu, F. 2008. Local blockade of TSLP receptor alleviated allergic disease by regulating airway dendritic cells. Clin Immunol 129, 202-210.

17. Tonozuka, Y., Fuijo, K., Sugiyama, T., Nosaka, T., Hirai, M. and Kitamura, T. 2001. Molecular cloning of a human novel type I cytokine receptor related to d1/TSLPR. Cytogenet Cell Genet 93, 23-25.

18. van der Heide, A., Jacobs, J. W., Haanen, H. C. and Bijlsma, J. W. 1995. Is it possible to predict the first year extent of pain and disability for patients with rheumatoid arthritis? $J$ Rheumatol 22, 1466-1470.

19. Watanabe, N., Wang, Y. H. and Lee, H. K. 2005. Hassall's corpuscles instruct dendritic cells to induce $\mathrm{CD} 4^{+} \mathrm{CD} 25^{+}$regulatory $\mathrm{T}$ cells in human thymus. Nature 436, 1181-1185.

20. Ying, S., O'Connor, B., Ratoff, J., Meng, Q., Mallett, K., Cousins, D., Robinson, D., Zhang, G., Zhao, J., Lee, T. H. and Corrigan, C. 2005. Thymic stromal lymphopoietin expression is increased in asthmatic airways and correlates with expression of Th2-attracting chemokines and disease severity. J Immunol 174, 8183-8190.

21. Yu, J. I., Kang, I. H., Chun, S. W., Yun, K. J., Moon, H. B. and Chae, S. C. 2010. Identifying the polymorphisms in the thymic stromal lymphopoietin receptor (TSLPR) and their association with asthma. BMB Rep 43, 499-505.

22. Zhang, M. H., Kim, Y. S., Jin, E. H., Kim, K. M., Lee, J. H., Li, C. S., Zhang, Q. G., Yun, K. J., Chae, S. C. and Chung, H. T. 2008. Identification of polymorphisms in thymic stromal lymphopoietin (TSLP) gene and their association with allergic rhinitis. Genes Genomics 30, 291-299.

23. Zhang, W., Wang, J. and Wang, Q. 2001. Identification of a novel type I cytokine receptor CRL2 preferentially expressed by human dendritic cells and activated monocytes. Biochem Biophys Res Commun 281, 878-883.

\title{
초록 : 한국인 류마티스 관절염의 감수성과 TSLPR 유전자 다형성의 연관성
}

\author{
유지인 · 모지수 · 채수천*
}

(원광대학교 의과대학 병리학교실)

사람의 TSLPR는 염증 유발 및 알러지 반응에 중요한 역할을 한다. 우리는 TSLPR 유전자에서 11개의 유전자 다형성과 2개의 유전적 변이 부위를 발굴하였고, 이들 TSLPR 유전자 다형성이 아토피 천식의 민감성과 연관성이 있음을 확인 하였다. 이에 우리는 TSLPR 유전자 다형성과 류마티스 관절염과의 연관성에 대해서도 알아 보고자 하였다. 457명의 류마티스 관절염 환자군과 570명의 정상 대조군으로 TSLPR 유전자 다형성의 genotype과 allele frequencies를 비교 분석 해본 결과 두 그룹 간에 유의성이 없었고, 류마티스 관절염 여성 그룹에서의 비교 분석 에서도 두 그룹 간에 유의성이 없었다. 또한, 류마티스 관절염 환자에서 TSLPR 유전자 다형성이 RF나 CCP levels에 영향을 미치지 않는 것으로 분석 되었다. 따라서, TSLPR 유전자 다형성이 한국인에서의 류마티스 관절염에 대한 민감성과 연관성이 없는 것으로 생각된다. 